\section{Late Harvest and Delayed Cooling Induce Internal Browning of 'Ya Li' and 'Seuri' Chinese Pears}

\author{
Carlos H. Crisosto', David Garner ${ }^{2}$, and Gayle M. Crisosto ${ }^{2}$ \\ Pomology Department, University of California, Parlier, CA 93648
}

\author{
Steve Sibbett ${ }^{3}$ and Kevin R. Day ${ }^{3}$ \\ Tulare County Cooperative Extension, Visalia, CA 93291
}

Additional index words. harvest date, storage temperature, fruit skin color, delayed cooling, disorder, quality attributes

\begin{abstract}
Brown discoloration of the core, carpels, and flesh areas of 'Ya $\mathbf{L i}$ ' and 'Seuri' Chinese pears [Pyrus bretschmeideri (Rehd.)] depended on harvest date. Fruit harvested no later than 180 days after full bloom (3000 degree days) did not develop the disorder. Browning of the core and flesh tissues increased when cooling was delayed, but was not influenced by subsequent storage temperatures of 0,10 , or $20 \mathrm{C}$. In both cultivars, the onset of internal browning was evident after storage in fruit that had been harvested when skin color had changed from green to light green-yellow. Thus, skin color can be used to determine harvest date to avoid internal browninincidence during storage of ' $\mathrm{Ya} \mathrm{Li}$ ' and 'Seuri' Chinese pears.
\end{abstract}

The development of brown to dark-brown water-soaked areas in the core and/or flesh of 'Ya Li', 'Seuri', 'Tsu Li', 'Dansui Li', and 'Shin Li' Chinese pears during storage has been reported in several growing areas in the United States (Beutel, 1990). These symptoms appear in the core, flesh, or both, but there is no visible external indication of their presence (Crisosto et al., 1992). Whether browning of the core and flesh is induced by the same conditions is unknown, but both limit the opportunity to store and market Chinese pears.

Our preliminary studies during the 1991 season indicated that storage at $\leq 10 \mathrm{C}$ did not influence internal browning (IB) incidence of 'Seuri' pears harvested on 15 Sept. 1991. After 1 month of storage at 0,5 , or $10 \mathrm{C}, 50 \%$, $56 \%$, and $61 \%$ of the pears had the disorder, respectively (Crisosto et al., 1992). As the cause of IB in Chinese pears is not known (Downs et al., 1991; Kitamura et al., 1981) and, to our knowledge, no information about its control is available, we decided to evaluate the effect of harvest date and postharvest temperature management on browning and other quality attributes of 'Ya Li' and 'Seuri' Chinese pears.

\section{Materials and Methods}

Fruit collection. During the 1992 season, fruit samples were collected on $18,21,25$, and

Received for publication 10 May 1993. Accepted for publication 16 Dec. 1993. We thank Themis Michailaides,TadKazuki,MikeHarvey,andGeorge Jacksonfortheir support. The cost of publishing this paper was defrayed in part by the payment of page charges.Under postal regulations, this paper thereforemustbe herebymarked advertisement solely to indicate this fact.

'PostharvestPhysiologist.

${ }^{2}$ Staff Research Associate.

${ }^{3}$ Extension Farm Advisor.
28 Aug. and 3 and 11 Sept. for 'Ya Li' and on 21 and 25 Aug. and 3, 11, 17, and 23 Sept. for 'Seuri' from an orchard located near Kingsburg, symbols are not shown.
Calif. The fruit samples were collected from 10 days before until 10 days after the commercial harvest period (Griggs and Iwakiri, 1977) to include fruit with green to yellow skin for each cultivar. Fruit were collected from five randomly selected healthy and mature trees, each of which served as a replication. Fruit quality was measured at harvest and after fruit had been "stored 1 month at 0,10 , or $20 \mathrm{C}$. Postharvest data were analyzed using analysis of variance and mean separations. The SAS program (SAS Institute, 1988) was used for statistical comparisons.

Initial fruit quality. Quality evaluations included measurements of skin color, flesh firmness, soluble solids concentration (SSC), and IB development on 20 fruit from each of the five replications. Skin color was measured with a Minolta Chromameter CR-200 (Minolta Corp., Ramsey, N. J.) using two color parameters ( $a^{*}$ and $b^{*}$ values). Hue angle (arctan $b^{*} /$ $\left.a^{*}\right)$, color intensity indicator useful for determining color differences in fruit that ripen from green to either yellow or shades of red, was calculated from $\mathrm{a}^{*}$ and $\mathrm{b}^{*}$ values according to McGuire's suggestion (1992). Color was measured twice at the fruit's equator (side), and twice at its blossom end (bottom). Average color readings were then determined for both of these locations for each fruit. Care was taken to exclude any areas affected by solar

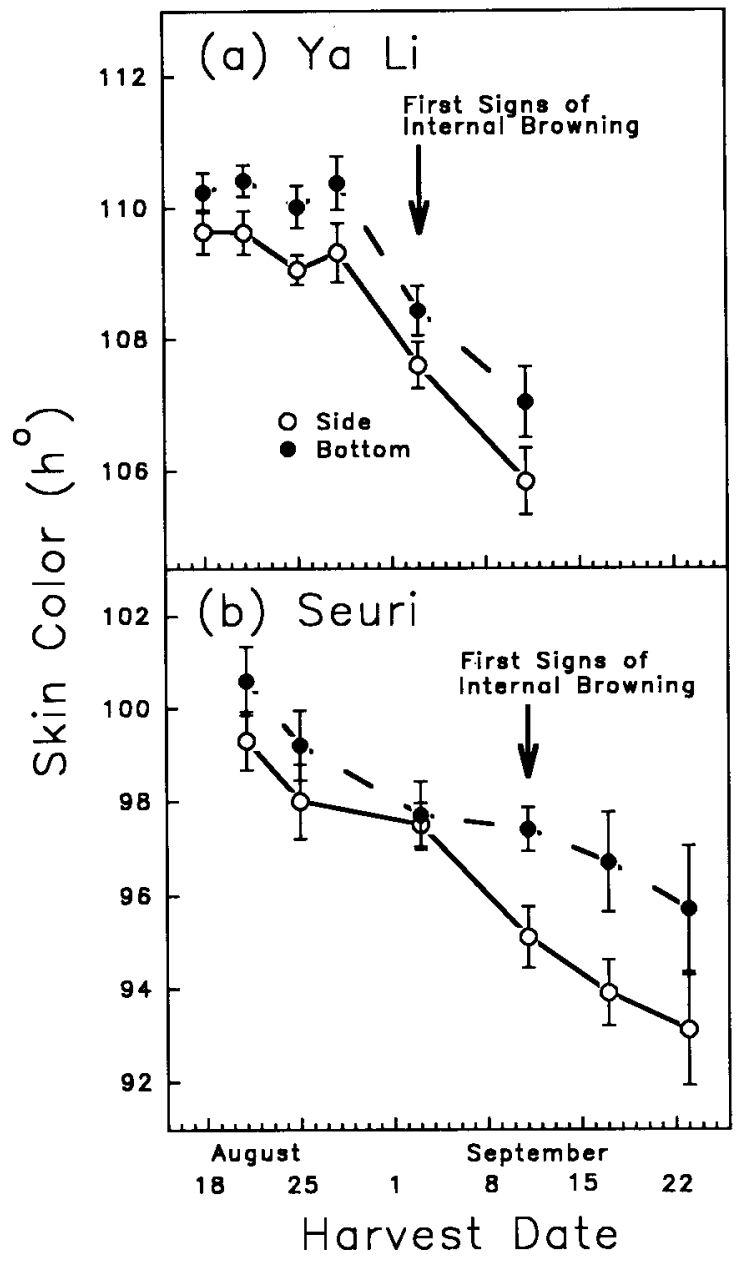

تig. 1. Skin color ( $\mathrm{h}^{\circ}$ values) as measured at the fruit's equator (side) or blossom end (bottom) on various harvest dates for (a) 'Ya Li' and (b) 'Seuri' Chinese pears. Vertical bars represent $\pm \mathrm{sE}$; bars smaller than 
injury from color measurement. Flesh firmness was measured using a U.C. firmness tester with an 8-mm tip (Western Industrial Supply, San Francisco). Skin from opposite cheeks of each fruit was removed and flesh firmness calculated as an average of two measurements per fruit and expressed in newtons. Next, the pears were cut in half transversely and two wedges from opposite sides of each fruit removed and combined with others from within the replication to form a composite sample. From this composite sample, juice was extracted with a hand press, filtered through cheesecloth, and SSC measured using a temperature-compensated refractometer. Any browning of the core and/or flesh of the halved fruit was recorded.

Storage performance. To study the effect of storage temperature on IB symptom development, 20 fruit from each of the five replications per cultivar per harvest date were volume-packed in corrugated boxes without liners and placed at 0,10 , or $20 \mathrm{C}$ and $90 \%$ relative humidity. Fruit quality and IB were measured after 1 month of storage as described. Individual fruit from each treatment were carefully weighed and labeled to measure water loss during storage. After 1 month of storage, the fruit were reweighed, and weight loss was calculated as the percent reduction from the initial weight,

Delayed cooling. To study the effect of delayed cooling on fruit quality and IB incidence, five replications of 20 fruit each were held at $20 \mathrm{C}$ for 7 days to ripen before storage for 21 days at $0 \mathrm{C}(20 / 0 \mathrm{C})$. After this period, fruit quality and IB incidence were determined as described.

\section{Results and Discussion}

Harvest quality. Average hue $\left(\mathrm{h}^{\circ}\right)$ color values as measured at harvest decreased slowly in both cultivars during our collection period (Fig. $1 \mathrm{a}$ and b). Position of the measurements (side or bottom) did not influence hue values except for 'Seuri', where values taken on the side, but not on the bottom, changed color intensity sharply after 3 Sept. (Fig. 1 b). Changes in harvest hue values were detected on and after 3 Sept. on 'Ya Li' (Fig. 1a) and on and after 11 Sept. on 'Seuri' (Fig. lb). In both cultivars, these changes in skin hue color values coincided with the appearance of a light green-yellow pigmentation.

Fruit firmness in 'Ya Li' remained at $\approx 50 \mathrm{~N}$ until 28 Aug., followed by a steady decrease to $\approx 40 \mathrm{~N}$ on 11 Sept. (Fig. 2a). A constant decline in fruit firmness occurred in 'Seuri' (Fig. 2b) during the harvesting period. On each harvest date, initial fruit firmness was always higher for 'Seuri' than for 'Ya Li', but SSC was similar in both cultivars. Harvest date had no effect on SSC within the duration of our experiment for 'Ya Li' (Fig. 2a) or 'Seuri' (Fig. 2b). IB symptoms were absent in all fruit samples examined at harvest.

Storage quality. Skin color did not visibly change in 'Ya Li' or' Seuri' during OC storage. Fruit stored at 20 or $10 \mathrm{C}$ had the capacity to turn yellow after 1 month of storage, regard-

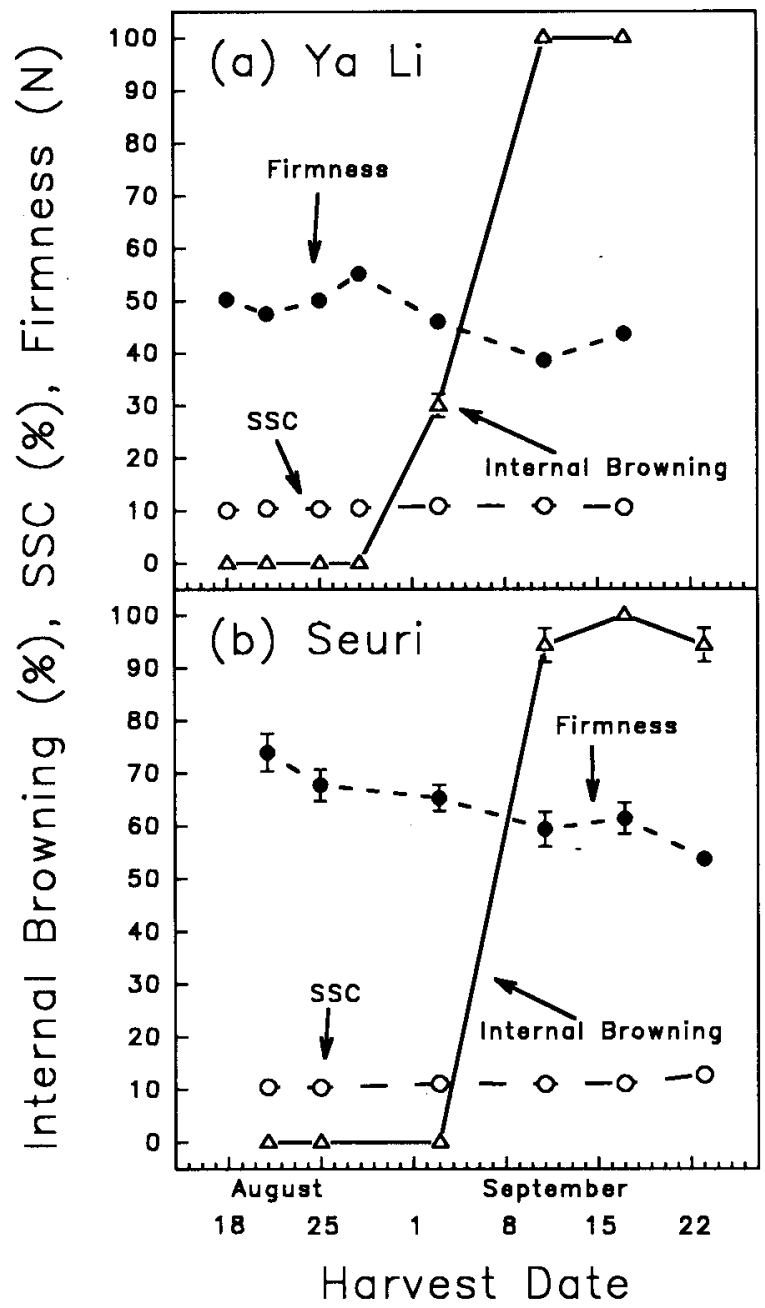

Fig. 2. Firmness and soluble solids concentration (SSC) measured at harvest and internal browning incidence following 1 month of storage for (a) 'Ya Li' and (b) 'Seuri' Chinese pears. Vertical bars represent \pm SE; bars smaller than symbols are not shown.

Table 1. Influence of storage for 1 month at several temperatures on 'Ya Li' Chinese pear fruit quality.

\begin{tabular}{|c|c|c|c|c|}
\hline $\begin{array}{l}\text { Harvest } \\
\text { date }\end{array}$ & $\begin{array}{c}\text { Storage } \\
\text { temp } \\
\left({ }^{\circ} \mathrm{C}\right)\end{array}$ & $\begin{array}{c}\text { Color }^{2} \\
\left(\mathrm{~h}^{\circ}\right)\end{array}$ & $\begin{array}{c}\text { Firmness } \\
(\mathrm{N})\end{array}$ & $\begin{array}{c}\text { Internal } \\
\text { browning } \\
(\%)\end{array}$ \\
\hline \multirow[t]{3}{*}{18 Aug. } & 0 & 109 & 47.7 & 0 \\
\hline & 10 & 104 & 45.5 & 0 \\
\hline & 20 & 97 & 44.6 & 0 \\
\hline \multirow[t]{3}{*}{21 Aug. } & 0 & 110 & 48.6 & 0 \\
\hline & 10 & 105 & 48.2 & 0 \\
\hline & 20 & 99 & 46.8 & 0 \\
\hline \multirow[t]{3}{*}{25 Aug. } & 0 & 110 & 50.0 & 0 \\
\hline & 10 & 103 & 45.5 & 0 \\
\hline & 20 & 98 & 50.2 & 0 \\
\hline \multirow[t]{3}{*}{28 Aug. } & 0 & 110 & 50.0 & 0 \\
\hline & 10 & 105 & 49.0 & 0 \\
\hline & 20 & 101 & 50.4 & 0 \\
\hline \multirow[t]{3}{*}{3 Sept. } & 0 & 108 & 44.1 & 30 \\
\hline & 10 & 101 & 42.3 & 30 \\
\hline & 20 & 96 & 41.0 & 44 \\
\hline \multirow[t]{3}{*}{11 Sept. } & 0 & 104 & 37.8 & 100 \\
\hline & 10 & 100 & 40.5 & 100 \\
\hline & 20 & 96 & 37.4 & 100 \\
\hline \multicolumn{5}{|c|}{ Significance } \\
\hline \multicolumn{2}{|c|}{ Date } & $*$ & $*$ & $*$ \\
\hline \multicolumn{2}{|c|}{ Treatment } & $*$ & $*$ & NS \\
\hline \multicolumn{2}{|c|}{ Date $\times$ treatment } & $*$ & $*$ & NS \\
\hline
\end{tabular}

${ }^{7} \mathrm{~h}^{\circ}$ (from $\left.\arctan \mathrm{b}^{*} / \mathrm{a}^{*}\right)$ is the hue angle $\left(0^{\circ}=\right.$ red-purple, $90^{\circ}=$ yellow, $180^{\circ}=$ bluish-green, $\left.270^{\circ}=\mathrm{blue}\right)$. Values are an average of two measurements on the blossom end of the fruit and two on the cheeks per each of the five replications. Measurements were taken after 1 month of storage.

Ns. *Nonsignificant or significant at $P \leq 0.05$ within columns using the F test. 
less of harvest time. Generally, the skin became a bright yellow after 1 month at $20 \mathrm{C}$ and a light yellow after 1 month at 10C (Tables 1 and 2).

During storage, fruit firmness was related to holding temperature and harvest date for both cultivars. For 'Seuri', storage at 20C resulted in softer fruit than storage at 0 or $10 \mathrm{C}$. In both cultivars, fruit harvested on or after 3 Sept. and stored at any of the temperatures were softer than fruit picked earlier in the season. Storage temperatures had no influence on SSC in 'Ya Li' (range $9.7 \%$ to $10.8 \%$ ) or 'Seuri' (range $10.9 \%$ to $12.8 \%$ ) measured after 1 month of storage. Both cultivars had similar weight loss: $5 \%, 2 \%$, and $1.5 \%$ after storage at 20,10 , and $0 \mathrm{C}$, respectively.
Browning in the core and flesh was not influenced by storage temperatures (Tables 1 and 2), except when cooling was delayed. IB did, however, depend on harvest date. Symptoms became visible after 1 month of storage in fruit harvested on and after 3 Sept. for 'Ya Li' (Fig. 2a) and on and after 11 Sept. for 'Seuri' (Fig. 2b). On fruit of both cultivars harvested on or after 11 Sept., between $83 \%$ and $100 \%$ showed IB symptoms after 1 month of storage. These symptoms appeared as brown discoloration of the core and carpel areas, and in most cases, the brown core was accompanied by dark-brown, water-soaked areas; translucent, soft, light-brown areas; or both in the fruit flesh.

Fruit always had a higher incidence of

Table 2. Influence of storage for 1 month at several temperatures on 'Seuri' Chinese pear fruit quality.

\begin{tabular}{lcccc}
\hline \hline $\begin{array}{l}\text { Harvest } \\
\text { date }\end{array}$ & $\begin{array}{c}\text { Storage } \\
\text { temp } \\
\left({ }^{\circ} \mathrm{C}\right)\end{array}$ & $\begin{array}{c}\text { Color } \\
\left(\mathrm{h}^{\circ}\right)\end{array}$ & $\begin{array}{c}\text { Firmness } \\
(\mathrm{N})\end{array}$ & $\begin{array}{r}\text { Internal } \\
\text { browning } \\
(\%)\end{array}$ \\
\hline 21 Aug. & 0 & 97 & 58.5 & 0 \\
& 10 & 91 & 61.7 & 0 \\
25 Aug. . & 20 & 82 & 45.0 & 0 \\
& 0 & 99 & 64.4 & 0 \\
3 Sept. & 10 & 89 & 68.0 & 0 \\
& 20 & 84 & 47.3 & 0 \\
11 Sept. & 0 & 97 & 58.5 & 0 \\
& 10 & 89 & 61.2 & 0 \\
17 Sept. & 20 & 83 & 42.8 & 100 \\
& 0 & 93 & 58.1 & 83 \\
23 Sept. & 10 & 86 & 50.4 & 100 \\
& 20 & 83 & 39.2 & 100 \\
Significance & 0 & 91 & 54.5 & 94 \\
Date & 10 & 86 & 54.0 & 100 \\
Treatment & 20 & 93 & 35.6 & 100 \\
Date $\times$ treatment & 0 & 87 & 56.3 & $*$ \\
\hline
\end{tabular}

$2 \mathrm{~h}^{\circ}\left(\right.$ from $\left.\arctan \mathrm{b}^{*} / \mathrm{a}^{*}\right)$ is the hue angle $\left(0^{\circ}=\right.$ red-purple, $90^{\circ}=$ yellow, $180^{\circ}=$ bluish-green, $270^{\circ}=$ blue $)$. Values are an average of two measurements on the blossom end of the fruit and two on the cheeks per each of the five replications. Measurements were taken after 1 month of storage.

Ns, ${ }^{*}$ Nonsignificant or significant at $P \leq 0.05$ within columns using the $\mathrm{F}$ test.

Table 3. Internal browning incidence and fruit quality characteristics of ' $\mathrm{Ya} \mathrm{Li}$ ' Chinese pear stored at $\mathrm{OC}$ for 28 days $(0)$ or held for 7 days at $20 \mathrm{C}$ before storage at $0 \mathrm{C}$ for 21 days $(20 / 0)$.

\begin{tabular}{|c|c|c|c|c|}
\hline $\begin{array}{l}\text { Harvest } \\
\text { date }\end{array}$ & $\begin{array}{l}\text { Storage } \\
\text { temp } \\
\left({ }^{\circ} \mathrm{C}\right)\end{array}$ & $\begin{array}{c}\text { Color }^{2} \\
\left(\mathrm{~h}^{\circ}\right)\end{array}$ & $\begin{array}{c}\text { Firmness } \\
(\mathrm{N})\end{array}$ & $\begin{array}{c}\text { Internal } \\
\text { browning } \\
(\%)\end{array}$ \\
\hline \multirow[t]{2}{*}{18 Aug. } & 0 & 109 & 47.7 & 0 \\
\hline & $20 / 0$ & 108 & 46.4 & 0 \\
\hline \multirow{2}{*}{21 Aug. } & 0 & 110 & 48.6 & 0 \\
\hline & $20 / 0$ & 108 & 45.5 & 0 \\
\hline \multirow{2}{*}{25 Aug. } & 0 & 110 & 45.5 & 0 \\
\hline & $20 / 0$ & 108 & 46.4 & 44 \\
\hline \multirow[t]{2}{*}{28 Aug. } & 0 & 109 & 45.5 & 0 \\
\hline & $20 / 0$ & 107 & 46.4 & 45 \\
\hline \multirow[t]{2}{*}{3 Sept. } & 0 & 108 & 44.1 & 30 \\
\hline & $20 / 0$ & 103 & 43.2 & 89 \\
\hline \multirow[t]{2}{*}{11 Sept. } & 0 & 103 & 41.9 & 100 \\
\hline & $20 / 0$ & 102 & 39.6 & 100 \\
\hline \multicolumn{5}{|c|}{ Significance } \\
\hline \multicolumn{2}{|c|}{ Date } & $*$ & * & * \\
\hline \multicolumn{2}{|c|}{ Treatment } & * & NS & * \\
\hline \multicolumn{2}{|c|}{ Date $\times$ treatment } & * & NS & * \\
\hline
\end{tabular}

${ }^{2} \mathrm{~h}^{\circ}\left(\right.$ from arctan $\left.\mathrm{b}^{*} / \mathrm{a}^{*}\right)$ is the hue angle $\left(0^{\circ}=\right.$ red-purple, $90^{\circ}=$ yellow, $180^{\circ}=$ bluish-green, $270^{\circ}=$ blue $)$. Values are an average of two measurements on the blossom end of the fruit and two on the cheeks per each of the five replications. Measurements were taken after 1 month of storage.

Ns. *Nonsignificant or significant at $P \leq 0.05$ within columns using the $\mathrm{F}$ test. browning in the core than in the flesh, and we never observed flesh browning without browning in the core, which suggests that the disorder begins in the core and then progresses toward the flesh. Thus, these symptoms are similar to those of core breakdown in 'Bartlett', 'Bose', 'Cornice', and 'Clapp Favorite' pear (Pyrus communism L.) cultivars as described by Porritt et al. (1982). More detailed work is needed to explain which physiological changes during fruit maturation and senescence are causing this disorder. Some fruit showed brown fungal development in the core and carpel areas at harvest and after storage. After isolation, Alternaria sp. were found to be associated with brown areas in the pear's core in $\leq 3 \%$ of the samples, but not with the darkbrown, water-soaked and translucent soft areas of the fruit flesh.

In both cultivars, the onset of internal browning was evident after storage in fruit that had been harvested when skin color had changed from green to light green-yellow (Fig. $1 \mathrm{a}$ and $\mathrm{b}$ ). Therefore, skin color changes from green to light green-yellow during maturation can be used to determine harvest date to avoid internal browning development during subsequent storage of 'Ya Li' and 'Seuri' Chinese pears.

Delayed cooling. Holding fruit at $20 \mathrm{C}$ for 1 week before 3 weeks of storage at $0 \mathrm{C}$ promoted skin yellowing in 'Ya Li' (Table 3 ) and 'Seuri' (Table 4). For both cultivars, a difference in yellow skin-color intensity following storage was observed between immediate and delayed cooling. On fruit harvested on or after 11 Sept., however, these differences in skin color were minor. Delayed cooling did not alter flesh firmness of 'Ya Li' (Table 3) or 'Seuri' (Table 4), nor SSC ('Ya Li' range 9.7\% to $10.6 \%$; 'Seuri' range $11.4 \%$ to $12.9 \%$ ).

Delayed cooling promoted IB development in both pear cultivars. Symptoms of IB were first observed after delayed-cooling storage of 'Ya Li' harvested 25 Aug. and of 'Seuri' harvested 3 Sept. when the fruit skin was still green. Thus, the delayed cooling treatment accelerated IB development by nearly 7 days in 'Seuri' and 9 days in 'Ya Li'. These IB symptoms were induced by delayed cooling in fruit that did not develop the disorder when stored immediately at 0,10 , or $20 \mathrm{C}$. This result suggests that ripening predisposes the fruit to the disorder while it is in cold storage. The possibility does exist, however, that different mechanisms can cause the same IB symptoms, whether influenced by delayed cooling or late harvest. Fruit of both cultivars harvested on or after 11 Sept. were affected by such a high degree of IB after 1 month of storage that delayed cooling showed no additional deleterious effects.

Conclusions. IB can be avoided by harvesting Chinese pears earlier than is presently done commercially in the San Joaquin Valley of California. Fruit grown under California conditions and picked later than 180 days (3000 degree days) after full bloom are likely to develop browning during storage. Degree days were calculated by averaging the daily maximum and minimum temperatures, sub- 
Table 4. Internal browning incidence and fruit quality characteristics of 'Seuri' Chinese pear stored at $0 \mathrm{C}$ for 28 days ( 0 ) or held for 7 days at $20 \mathrm{C}$ before storage at $0 \mathrm{C}$ for 21 days $(20 / 0)$.

\begin{tabular}{|c|c|c|c|c|}
\hline $\begin{array}{l}\text { Harvest } \\
\text { date }\end{array}$ & $\begin{array}{c}\text { Storage } \\
\text { temp. } \\
\left({ }^{\circ} \mathrm{C}\right)\end{array}$ & $\begin{array}{l}\text { Color }^{2} \\
\left(\mathrm{~h}^{\circ}\right)\end{array}$ & $\begin{array}{c}\text { Firmness } \\
(\mathrm{N})\end{array}$ & $\begin{array}{c}\text { Internal } \\
\text { browning } \\
(\%)\end{array}$ \\
\hline \multirow[t]{2}{*}{21 Aug. } & 0 & 97.5 & 58.5 & 0 \\
\hline & $20 / 0$ & 93.4 & 61.7 & 0 \\
\hline \multirow[t]{2}{*}{25 Aug. } & 0 & 98.7 & 61.7 & 0 \\
\hline & $20 / 0$ & 91.4 & 61.7 & 0 \\
\hline \multirow[t]{2}{*}{3 Sept. } & 0 & 97.3 & 58.5 & 0 \\
\hline & $20 / 0$ & 91.9 & 59.0 & 56 \\
\hline \multirow[t]{2}{*}{11 Sept. } & 0 & 93.5 & 58.1 & 94 \\
\hline & $20 / 0$ & 87.3 & 54.0 & 100 \\
\hline \multirow[t]{2}{*}{17 Sept. } & 0 & 90.8 & 54.9 & 100 \\
\hline & $20 / 0$ & 87.7 & 51.8 & 100 \\
\hline \multirow[t]{2}{*}{23 Sept. } & 0 & 90.4 & 59.0 & 94 \\
\hline & $20 / 0$ & 88.0 & 53.6 & 100 \\
\hline \multicolumn{5}{|c|}{ Significance } \\
\hline \multicolumn{2}{|c|}{ Date } & * & * & * \\
\hline \multicolumn{2}{|c|}{ Treatment } & * & NS & *. \\
\hline \multicolumn{2}{|c|}{ Date $\times$ treatment } & * & NS & * \\
\hline
\end{tabular}

${ }^{\mathrm{t}} \mathrm{h}^{\circ}$ (from arctan $\left.\mathrm{b}^{*} / \mathrm{a}^{*}\right)$ is the hue angle $\left(0^{\circ}=\right.$ red-purple, $90^{\circ}=$ yellow, $180^{\circ}=$ bluish-green, $270^{\circ}=$ blue $)$. Values are an average of two measurements on the blossom end of the fruit and two on the cheeks per each of the five replications. Measurements were taken after 1 month of storage.

ws. Nonsignificant or significant at $P \leq 0.05$ within columns using the $\mathrm{F}$ test.

tracting $4 \mathrm{C}$, and summing the resulting values (Johnson and Lakso, 1985). First symptoms of IB were observed after 1 month of storage in 'Ya Li' fruit harvested 3215 degree days (3 Sept.) from full bloom and in 'Seuri' picked 3299 degree days (11 Sept.) from full bloom.

The fruit should be picked when most of the pears on the tree are still green, although a few at the top may begin to develop some light-yellow spots. Fruit picked when the skin month after harvest. Prompt cooling of fruit is recommended as delays in cooling increase the incidence of IB on pears that are beginning to yellow.

We suggest that growers who are having IB problems in Chinese pears keep records of the number of days after full bloom needed for their fruit to start turning light yellow to help is completely yellow will develop IB within 1 them decide when to pick in subsequent years. Fruit size and SSC can be maximized by proper pollination and thinning (Beutel, 1990) rather than delayed harvesting.

\section{Literature Cited}

Beutel, J, 1990. Asian pears, p. 304-308. In: J Janick and J.E. Simon (eds.). Advances in new crops. Timber Press, Portland, Ore.

Crisosto, C., D. Garner, S. Sibbett, and K. Day. 1992. Maturity studies on Asian pear. Central Valley Postharvest Nwsl. 1(2):1-3.

Downs, C. G., C.J. Brady, J. Campbell, and W.B. McGlasson.1991. Normal ripening cultivars of Pyrus serotina are either climacteric or non-climacteric.ScientiaHort.48:2 13-221.

Griggs, W. and B. Iwakiri. 1977. Asian pear varieties in California. Univ. of California DANR Publ. 4068, Oakland

Johnson, R.S. and A.N. Lakso. 1985, Relationships between stem length, leaf area, stem weight, and accumulated growing degree-days in apple shoots. J. Amer. Soc. Hort. Sci. 110:586-590.

Kitamura,T.,T.Iwata,T.Fukushima, Y. Furukawa, andT.Ishaguro.1981.Studieson the maturation physiology and storage of fruit and vegetables. II.Respirationandethyleneproduction in referencetospecies and cultivars of pear fruit. J. Jpn. Soc. Hort. Sci. 49:608-616.

McGuire, R.G. 1992. Reporting of objective color measurements,HortScience 27:1254-1255.

Porritt,S.W.,M.Meheriuk,andP.D. Lindster. 1982. Postharvest disorders of apples and pears. Agr. Canada Publ. 1737/E.

SAS Institute. 1988. SAWSTAT user's guide. Release 6.03 ed. SAS Inst., Cary, N.C. 